\title{
Retrospective Serological Tests for Determining the Optimal Blood Concentration of Voriconazole for Treating Fungal Infection
}

\author{
Toshikatsu OKUDA, ${ }^{*}$ Akiko OKUDA, Noriko WatANABE, \\ Masayoshi TAKAO, and Kazunobu TAKAYANAGI \\ Department of Pharmacy, Kurashiki Central Hospital, 1-1-1 Miwa, Kurashiki City 710-8602, Japan
}

(Received May 7, 2008; Accepted September 8, 2008)

\begin{abstract}
We investigated the optimal blood concentration of voriconazole (VRCZ) based on trough blood concentrations (C) and serological test values in patients. With regard to the regulation of VRCZ dosage (D) to maintain optimal blood concentrations, we investigated the relationship between $\mathrm{C}$ and $\mathrm{D}$. Twenty-three patients were enrolled in the present study, and at 28 point data were analyzed retrospectively.

When the $\beta$-D-glucan or the Aspergillus antigen were decreased below the standard set values, it was evaluated as effective. The adverse events were evaluated using the Common Terminology Criteria for Adverse Events ver. 3.0. We found a significant difference $(p<0.05)$ in the average trough blood concentration between patients in whom VRCZ was effective and those in whom VRCZ was ineffective $(8.21 \pm 2.19 \mu \mathrm{g} / \mathrm{ml} v s .1 .01 \pm 0.86 \mu \mathrm{g} / \mathrm{ml})$, and patients presenting with adverse events and those with no adverse events $(7.64 \pm 2.84 \mu \mathrm{g} / \mathrm{ml} v s .1 .49 \pm 1.79 \mu \mathrm{g} / \mathrm{ml})$. There was no significant relationship between C and D (C: D, $\left.y=0.018-2.186, r^{2}=0.349\right)$.

Improved efficacy and more adverse events thus occurred with higher blood concentrations. The careful regulation of the dosage must be performed while measuring blood concentration and observing for adverse events. The implementation of therapeutic drug monitoring for VRCZ is a valuable tool for achieving effective fungal infection therapy and should be aggressively investigated in future studies.
\end{abstract}

Key words - optimal blood concentration; Voriconazole (VRCZ); fungal infection; serological test; trough blood concentration; therapeutic drug monitoring (TDM)

\section{INTRODUCTION}

Voriconazole (VRCZ) is an effective drug for treating a broad spectrum of fungal infections with high fungal activity such as those caused by Candida glabrata, Candida krusei, and other species belonging to the Candida, Aspergillus, and Cryptococcus families, which have low sensitivity to other intravenous drugs from the same azole group such as fluconazole. ${ }^{1-3)}$ This drug has both oral and IV forms, and because of its high bioavailability (about 100\%) when administered orally, it is also possible to change its route of administration (switch therapy). Moreover, this drug is much more convenient to administer than conventional medications. ${ }^{4)}$ Because of these characteristics, VRCZ has recently become a valuable, widely used medication for treating deep mycosis. ${ }^{5-8)}$

However, because this drug is primarily metabolized by cytochrome P450 (CYP2C19), 9) patients deficient in this enzyme show a shift in the blood concentration of the drug to abnormally high levels with

\footnotetext{
*e-mail: to7621@ kchnet.or.jp
}

accompanying adverse events. Particularly in Japanese patients, among whom those deficient in this enzyme is reported to range from 15 to $20 \%,{ }^{10)}$ it is necessary to exercise caution to avoid the adverse events. To prevent these adverse events, the implementation of therapeutic drug monitoring (TDM) is believed to be effective and is highly recommended. ${ }^{11,12)}$ On the other hand, in the TDM of VRCZ, particularly for evaluation in phase I and phase III studies in Japan, the trough blood concentrations in all patients in whom hepatic dysfunction occurred were reported to exceed $4.5 \mu \mathrm{g} / \mathrm{ml}$. However, the standards for therapeutically effective blood concentrations have not yet been identified. ${ }^{12)}$ Accordingly, more therapeutic results must be obtained, and based on clinical findings, it is necessary to clarify the standard blood concentration range of VRCZ. Consequently, based on the results of serologic tests from the measurements of the blood concentration of VRCZ in patients with deep mycosis at our facility, we performed a detailed evaluation of the therapeutic efficacy of VRCZ and its adverse effects and report here the results of our investigation of optimal blood concentrations. 


\section{PATIENTS AND METHODS}

Patients From January 2006 until December 2007, 23 patients (11 men and 12 women) were treated with VRCZ at our facility. We analyzed 28-point data from these patients which were collected retrospectively. When the dosage was altered or when drug administration was suspended and restarted even in the same patient, we performed a new evaluation and analysis. The background of our patients is given in Table 1, showing an age range of 18 to 85 years (mean \pm S.D., $58.2 \pm 23.2$ ) and a body weight range of 40 to $63 \mathrm{~kg}$ (mean \pm S.D., $51.8 \pm 8.97$ ). VRCZ concentration in the blood reached a steady level 5 days after the start of administration, and 5 days subsequent to any change in dosage. Because the trough blood concentration $(\mathrm{C})$ has been reported to be more important than the peak blood $\mathrm{C}$ when eval- uating VRCZ efficacy and safety, ${ }^{13-16)}$ we measured the trough blood C in this study. No patient was taking agents or food supplements (i.e., phenytoin, St. John's Wort, etc.), that influenced the blood drug C of VRCZ.

We conducted the present research in accordance with the Helsinki Declaration. Patient privacy was maintained.

Therapeutic Efficacy and Adverse Events Early diagnosis and treatment monitoring of infectious fungal diseases is based on monitoring changes in $\beta$-Dglucan and Aspergillus antigen. ${ }^{12,17-24)}$ We investigated fungal infectious diseases showing high levels of $\beta$ D-glucan and Aspergillus antigen and used the levels of these markers as an indication of the therapeutic efficacy of VRCZ.

As an indication of adverse events, we analyzed the levels of aspartate aminotransferase (AST), alanine

Table 1. Patient Characteristics

\begin{tabular}{|c|c|c|c|c|c|c|c|}
\hline ID & Sex & $\begin{array}{l}\text { Age } \\
\text { (year) }\end{array}$ & $\begin{array}{l}\text { Weight } \\
(\mathrm{kg})\end{array}$ & Underlying disease & Infectious disease & $\begin{array}{l}\text { Infection } \\
\text { location }\end{array}$ & $\begin{array}{l}\text { Detected } \\
\text { bacterium }\end{array}$ \\
\hline A & Female & 55 & 40 & Systemic lupus erythematous & Pulmonary aspergillosis & Lung & None \\
\hline $\mathrm{B}$ & Female & 19 & 50 & $\begin{array}{l}\text { Aggressive natural killer cell leu- } \\
\text { kaemia }\end{array}$ & Febrile Neutropenia & Uncertain & None \\
\hline $\mathrm{C}$ & Female & 49 & 51.3 & $\begin{array}{l}\text { Acute lymphatic leukaemia } \\
(\text { after BMT*) }\end{array}$ & Febrile Neutropenia & Uncertain & None \\
\hline $\mathrm{D}$ & Male & 32 & 45 & Acute myelogenous leukemia & Deep mycosis & Uncertain & None \\
\hline $\mathrm{E}$ & Male & 80 & 55 & Myelodysplastic syndrome & Fungus brain abscess & Brain abscess & None \\
\hline $\mathrm{F}$ & Male & 25 & 72 & Germinoma & Pulmonary aspergillosis & Lung & None \\
\hline $\mathrm{G}$ & Female & 50 & 50 & Multiple myeloma & Pulmonary aspergillosis & Lung & None \\
\hline $\mathrm{H}$ & Male & 77 & 49 & Myelodysplastic syndrome & Pulmonary aspergillosis & Lung & None \\
\hline I & Male & 77 & 47 & Myelodysplastic syndrome & Pulmonary aspergillosis & Lung & None \\
\hline $\mathrm{J}$ & Female & 18 & 60 & $\begin{array}{l}\text { Acute lymphatic leukaemia } \\
\left(\text { after } \mathrm{UCBT}^{* *}\right)\end{array}$ & Febrile Neutropenia & Uncertain & None \\
\hline $\mathrm{K}$ & Female & 85 & 50 & Empyema pleurae & Aspergillosis & Uncertain & None \\
\hline $\mathrm{L}$ & Male & 75 & 62.6 & Malignant lymphoma & Pulmonary aspergillosis & Lung & None \\
\hline M & Female & 77 & 51 & $\begin{array}{l}\text { Chronicity necrosis pulmonary } \\
\text { aspergillosis }\end{array}$ & Pulmonary aspergillosis & Lung & None \\
\hline $\mathrm{N}$ & Male & 29 & 47 & Myelodysplastic syndrome & Aspergillosis & Uncertain & None \\
\hline $\mathrm{O}$ & Male & 25 & 73 & Acute myelogenous leukemia & Fungus infection prevention & - & None \\
\hline $\mathrm{P}$ & Female & 62 & 40 & Fungus endocarditis & Fungus sepsis & Heart muscle & C. parapsilosis \\
\hline $\mathrm{Q}$ & Male & 64 & 63 & $\begin{array}{l}\text { Myelodysplastic syndrome } \\
(\text { after BMT*) }\end{array}$ & Aspergillosis & Uncertain & None \\
\hline $\mathrm{R}$ & Female & 84 & 40 & Aplastic anemia & Deep mycosis & Uncertain & None \\
\hline $\mathrm{S}$ & Female & 65 & 52 & $\begin{array}{l}\text { Myelodysplastic syndrome } \\
\left(\text { after } \mathrm{BMT}^{*}\right)\end{array}$ & Fungus infection prevention & - & None \\
\hline $\mathrm{T}$ & Female & 50 & 45.6 & Acute myelogenous leukemia & Febrile Neutropenia & Uncertain & None \\
\hline $\mathrm{U}$ & Male & 79 & 52.2 & Myelodysplastic syndrome & Febrile Neutropenia & Uncertain & None \\
\hline $\mathrm{V}$ & Male & 77 & 49.2 & Myelodysplastic syndrome & Pulmonary aspergillosis & Lung & None \\
\hline $\mathrm{W}$ & Female & 84 & 47.6 & Acute myelogenous leukemia & Febrile Neutropenia & Lung? & None \\
\hline
\end{tabular}

* BMT: Bone Marrow Transplantation, ** UCBT: Umbilical cord blood transplantation. 
aminotransferase, and serum creatine $(\mathrm{Cr})$ levels obtained in serologic tests. Based on the changes in each value before and after blood $\mathrm{C}$ measurements and other clinical symptoms, we investigated the therapeutic efficacy of VRCZ and the occurrence of adverse events.

Criteria We referred to the evaluation proposal obtained from clinical studies of VRCZ in Japan to determine therapeutic efficacy. As shown in Table 2, unique standards were established to determine the serologic efficacy of the drug. If either of the $\beta$-D-glucan or Aspergillus antigen decreased below the standard, it was evaluated as effective. The normal value of $\beta$-D-glucan using the Fungitec G Test MK Antiinterferent Set was assumed to be $0-19.9 \mathrm{pg} / \mathrm{ml}$. Similarly, the cut-off value of Aspergillus antigen using the ELISA method was assumed to be 0.5 . No patient had received drugs such as piperacillin/tazobactam that could influence the value of Aspergillus antigen and $\beta$-D-glucan. We classified the grade of adverse events based on the Common Terminology Criteria for Adverse Events ver. 3.0 (CTCAE v 3.0) ${ }^{25)}$ and defined an "adverse event" as any deviation in the serologic test values from the normal range, or if there was no change in the assessment of these values. VRCZ administration was suspended when an adverse event occurred and a causal relationship could not be negated. The normal range including the upper limit of normal (ULN) and the criteria for adverse events are summarized in Table 3.

Relationship between Trough Blood Concentration and Dosage We studied the regulation of VRCZ dosage by investigating the relationship between trough blood C and dosage. We designated " $D$ " as the daily dosage and " $\mathrm{d}$ " as the dosage divided by the patient's weight.

Measurement Based on the method outlined by Usuki et al., ${ }^{26)}$ we used high-performance liquid chromatography (HPLC) to measure the blood concentration of VRCZ. For this type of measurement, the detection limit was $0.02 \mu \mathrm{g} / \mathrm{ml}$, and the method had quantitative limits of $0.05 \mu \mathrm{g} / \mathrm{ml}$ for both drug changes within 1 day and between days. Measurements were performed by the outside institution SRL Co.

Statistical Processing Data are presented as mean \pm standard deviation, and statistical analysis was performed using regression analysis and

Table 2. Standards of Judgment in This Research

\begin{tabular}{|c|c|c|}
\hline Inspection item & Judgment & Condition \\
\hline \multirow[t]{4}{*}{$\beta$-D-glucan } & Effective & The value normalized from the anomalous value or the value has improved by $50 \%$ or more \\
\hline & Invariability & The value has not changed by $50 \%$ or more \\
\hline & Non-effective & $\begin{array}{l}\text { The value deteriorated from a normal value to the anomalous value or the value has deteriorat- } \\
\text { ed by } 50 \% \text { or more }\end{array}$ \\
\hline & Impossibility & $\begin{array}{l}\text { The judgment of the above-mentioned value was impossible because there is no change such as } \\
\text { a normal value or there is no inspection data }\end{array}$ \\
\hline \multirow[t]{4}{*}{ Aspergillus antigen } & Effective & $\begin{array}{l}\text { The value was made negative }(-) \text { from positive }(+) \text { or the antigenic value of } 0.5 \text { or more has } \\
\text { decreased }\end{array}$ \\
\hline & Invariability & The antigenic value of 0.5 or more has not changed \\
\hline & Non-effective & $\begin{array}{l}\text { The value was made positive }(+) \text { from negative }(-) \text { or the antigenic value of } 0.5 \text { or more in- } \\
\text { creased }\end{array}$ \\
\hline & Impossibility & $\begin{array}{l}\text { The judgment of the above-mentioned value was impossible because there is no change such as } \\
\text { a normal value or there is no inspection data }\end{array}$ \\
\hline
\end{tabular}

Table 3 The Normal Range of Serologic Tests and the Criteria of the Adverse Events

\begin{tabular}{llcccc}
\hline \hline $\begin{array}{c}\text { Grade of } \\
\text { adverse event }\end{array}$ & $\begin{array}{c}\text { grade } 0 \\
\text { (the normal range) }\end{array}$ & grade 1 & grade 2 & grade 3 & grade 4 \\
\hline $\mathrm{AST}$ & $10-35(\mathrm{IU} / \mathrm{l})$ & $>\mathrm{ULN}-2.5$ times ULN & $>2.5-5.0$ times ULN & $>5.0-20.0$ times ULN & $>20.0$ times ULN \\
$\mathrm{ALT}$ & $7-42(\mathrm{IU} / \mathrm{l})$ & $>\mathrm{ULN}-2.5$ times ULN & $>2.5-5.0$ times ULN & $>5.0-20.0$ times ULN & $>20.0$ times ULN \\
$\mathrm{Cr}(\mathrm{male})$ & $0.6-1.10(\mathrm{mg} / \mathrm{dl})$ & $>\mathrm{ULN}-1.5$ times ULN & $>1.5-3.0$ times ULN & $>3.0-6.0$ times ULN & $>6.0$ times ULN \\
$\mathrm{Cr}($ female $)$ & $0.45-0.80(\mathrm{mg} / \mathrm{dl})$ & $>\mathrm{ULN}-1.5$ times ULN & $>1.5-3.0$ times ULN & $>3.0-6.0$ times ULN & $>6.0$ times ULN \\
\hline
\end{tabular}

ULN: Upper limit of normal. 
Student's $t$-test between two groups. One-way analysis of variance (ANOVA) was performed for comparisons among three or more groups. If a significant difference was found, multiple-comparison tests were performed using Ryan's method. Significance was set at $<5 \%(p<0.05)$.

\section{RESULTS}

The test results for the assessment of the efficacy of VRCZ and those based on these results are shown in Table 4. Of these patients, 8 were simultaneously receiving additional drug therapy for fungal infection; however, this therapy showed no effect on the evaluations in the present study.

Table 5 shows the 11 patients in whom adverse events occurred. Of these patients, the adverse events that may have had a causal relationship with elevated levels of lactate dehydrogenase, creatine phosphate, and gamma-glutamyl transpeptidase (GTP), factors other than those included in the test results measured in this study, were nausea and hallucinations. Both events disappeared after suspending VRCZ administration. No events that influerced the treatment of underlying disease were caused by appropriate treatments.

The blood concentration of VRCZ and the significant difference for each evaluation are shown in Fig. 1. In contrast to the average trough blood $\mathrm{C}$ $(8.21 \pm 2.19 \mu \mathrm{g} / \mathrm{ml})$ among the patients in whom VRCZ was effective, that in patients in whom VRCZ was deemed ineffective was $1.01 \pm 0.86 \mu \mathrm{g} / \mathrm{ml}$. The blood C of VRCZ was significantly higher in patients

Table 4. Judgment Results of Serologic Effectiveness and Blood Drug Concentrations of VRCZ

\begin{tabular}{|c|c|c|c|c|c|c|c|c|c|c|c|}
\hline \multirow{2}{*}{ No. } & \multirow{2}{*}{ ID } & \multirow{2}{*}{$\begin{array}{c}\text { Dose } \\
(\mathrm{mg} / \text { day })\end{array}$} & \multirow{2}{*}{ Route } & \multirow{2}{*}{$\begin{array}{c}\mathrm{C} \\
(\mu \mathrm{g} / \mathrm{ml})\end{array}$} & \multicolumn{3}{|c|}{$\beta$-D-glucan } & \multicolumn{3}{|c|}{ Aspergillus antigen } & \multirow{2}{*}{$\begin{array}{l}\text { Adjunct antifungal } \\
\text { agent used }\end{array}$} \\
\hline & & & & & Before & After & Judgment & Before & After & Judgment & \\
\hline 1 & A & 300 & p.o. & 0.39 & 8.0 & - & Impossibility & $2.3(+)$ & $2.3(+)$ & Invariability & $\begin{array}{l}\mathrm{MCFG}^{*}(300 \mathrm{mg}), \\
\text { ITCZ }^{* *}(200 \mathrm{mg})\end{array}$ \\
\hline 2 & A & 320 & d.i.v. & 0.09 & 8.0 & - & Impossibility & $2.3(+)$ & $2.3(+)$ & Invariability & $\begin{array}{l}\mathrm{MCFG}^{*}(300 \mathrm{mg}), \\
\mathrm{ITCZ}^{* *}(200 \mathrm{mg})\end{array}$ \\
\hline 3 & $\mathrm{~B}$ & 400 & p.o. & 1.57 & 46.3 & 25.6 & Invariability & - & - & Impossibility & $\mathrm{MCFG}^{*}(150 \mathrm{mg})$ \\
\hline 4 & $\mathrm{C}$ & 200 & p.o. & 0.60 & 15.4 & 7.3 & Impossibility & - & - & Impossibility & - \\
\hline 5 & $\mathrm{D}$ & 400 & p.o. & 0.13 & 3.3 & 27.7 & Non-effective & - & - & Impossibility & $\mathrm{MCFG}^{*}(150 \mathrm{mg})$ \\
\hline 6 & $\mathrm{E}$ & 360 & d.i.v. & 1.43 & 14.2 & 16.0 & Impossibility & $0.1(-)$ & - & Impossibility & $\mathrm{AMPHB}^{* * *}(27 \mathrm{mg})$ \\
\hline 7 & $\mathrm{~F}$ & 400 & p.o. & 3.08 & 0.0 & 2.8 & Impossibility & $0.1(-)$ & - & Impossibility & - \\
\hline 8 & $\mathrm{G}$ & 400 & p.o. & 7.63 & 13.7 & - & Impossibility & $\geqq 5.0(+)$ & $\geqq 5.0(+)$ & Invariability & $\mathrm{MCFG}^{*}(150 \mathrm{mg})$ \\
\hline 9 & $\mathrm{G}$ & 200 & p.o. & 1.84 & 13.7 & - & Impossibility & $3.0(+)$ & $3.6(+)$ & Non-effective & - \\
\hline 10 & $\mathrm{H}$ & 400 & p.o. & 9.34 & 37.1 & 14.9 & Effective & $0.2(-)$ & - & Impossibility & - \\
\hline 11 & I & 200 & p.o. & 2.88 & 24.8 & 22.4 & Invariability & $0.2(-)$ & - & Impossibility & - \\
\hline 12 & $\mathrm{~J}$ & 400 & p.o. & 0.98 & 8.8 & 5.3 & Impossibility & $0.2(-)$ & $0.2(-)$ & Impossibility & - \\
\hline 13 & $\mathrm{~K}$ & 200 & d.i.v. & 1.39 & 79.0 & 55.1 & Invariability & $2.3(+)$ & $2.3(+)$ & Invariability & - \\
\hline 14 & $\mathrm{~L}$ & 400 & p.o. & 1.55 & 24.9 & 32.1 & Invariability & $0.4(-)$ & $0.3(-)$ & Impossibility & - \\
\hline 15 & M & 300 & d.i.v. & 4.21 & 10.2 & 9.1 & Impossibility & $0.8(+)$ & $0.4(-)$ & Effective & $\mathrm{MCFG}^{*}(150 \mathrm{mg})$ \\
\hline 16 & $\mathrm{~N}$ & 400 & p.o. & 10.75 & 17.0 & 14.4 & Impossibility & $0.7(+)$ & $0.4(-)$ & Effective & $\mathrm{MCFG}^{*}(150 \mathrm{mg})$ \\
\hline 17 & $\mathrm{O}$ & 400 & p.o. & 2.35 & - & - & Impossibility & - & - & Impossibility & - \\
\hline 18 & $\mathrm{P}$ & 800 & d.i.v. & 11.08 & 1439.9 & 1689.7 & Invariability & - & - & Impossibility & - \\
\hline 19 & $\mathrm{P}$ & 200 & d.i.v. & 0.30 & 5567.1 & 4613 & Invariability & - & - & Impossibility & - \\
\hline 20 & Q & 400 & p.o. & 7.64 & 6.5 & 4.7 & Impossibility & $1.0(+)$ & $0.5(+)$ & Effective & - \\
\hline 21 & Q & 300 & p.o. & 8.95 & 2.8 & 7.7 & Impossibility & $0.5(+)$ & $0.4(-)$ & Effective & - \\
\hline 22 & $\mathrm{R}$ & 200 & p.o. & 0.13 & 37.8 & 45.0 & Invariability & $0.1(-)$ & - & Impossibility & - \\
\hline 23 & $\mathrm{~S}$ & 200 & p.o. & 0.72 & 1.7 & 2.6 & Impossibility & $0.1(-)$ & $0.2(-)$ & Impossibility & - \\
\hline 24 & $\mathrm{~T}$ & 400 & p.o. & 4.46 & 2.2 & 3.9 & Impossibility & $0.1(-)$ & $0.1(-)$ & Impossibility & - \\
\hline 25 & $\mathrm{U}$ & 400 & p.o. & 10.38 & 51.1 & 16.0 & Effective & $1.0(+)$ & $0.5(+)$ & Effective & - \\
\hline 26 & $\mathrm{U}$ & 200 & p.o. & 1.07 & 16.0 & 20.6 & Non-effective & $0.5(+)$ & - & Impossibility & - \\
\hline 27 & $\mathrm{~V}$ & 400 & p.o. & 8.23 & 54.5 & 20.3 & Effective & $0.8(+)$ & $0.5(+)$ & Invariability & - \\
\hline 28 & $\mathrm{~W}$ & 400 & d.i.v. & 6.16 & 41.6 & 13.4 & Effective & $1.0(+)$ & $0.1(-)$ & Effective & - \\
\hline
\end{tabular}

* MCFG, Micafangin; ** ITCZ, Itoraconazole; *** AMPHB, Amphotericin B. 
Table 5 Judgment Results of Adverse Effects and Blood Drug Concentrations of VRCZ

\begin{tabular}{|c|c|c|c|c|c|c|c|c|c|}
\hline \multirow{2}{*}{ No. } & \multirow{2}{*}{$\begin{array}{c}\text { Dose } \\
\text { (mg/day) }\end{array}$} & \multirow{2}{*}{ Route } & \multirow{2}{*}{$\begin{array}{c}\mathrm{C} \\
(\mu \mathrm{g} / \mathrm{ml})\end{array}$} & \multicolumn{5}{|c|}{ Adverse effect } & \multirow{2}{*}{ Others } \\
\hline & & & & AST (IU/1) & & LT (IU/l) & & $\mathrm{r}(\mathrm{mg} / \mathrm{dl})$ & \\
\hline 8 & 400 & p.o. & 7.63 & $-2 \quad($ grade $0 \rightarrow 2)$ & -1 & $($ grade $0 \rightarrow 1)$ & \pm 0 & - & \\
\hline 10 & 400 & p.o. & 9.34 & $-1 \quad($ grade $0 \rightarrow 1)$ & -1 & (grade $0 \rightarrow 1$ ) & -1 & (grade $1 \rightarrow 2$ ) & \\
\hline 11 & 200 & p.o. & 2.88 & $-1 \quad($ grade $0 \rightarrow 1)$ & \pm 0 & - & \pm 0 & - & Discontinuance because of nausea \\
\hline 15 & 300 & d.i.v. & 4.21 & $-1 \quad($ grade $0 \rightarrow 1)$ & \pm 0 & - & \pm 0 & - & \\
\hline 16 & 400 & p.o. & 10.75 & \pm 0 & \pm 0 & - & \pm 0 & - & Hallucination \\
\hline 18 & 800 & d.i.v. & 11.08 & $-1 \quad($ grade $1 \rightarrow 2)$ & \pm 0 & - & -1 & (grade $0 \rightarrow 1)$ & \\
\hline 21 & 300 & p.o. & 8.95 & $-1 \quad($ grade $0 \rightarrow 1)$ & \pm 0 & - & \pm 0 & - & $\mathrm{LDH}^{* \uparrow}, \mathrm{CPK}^{* *} \uparrow$ \\
\hline 24 & 400 & p.o. & 4.46 & $-1 \quad($ grade $0 \rightarrow 1)$ & -1 & (grade $1 \rightarrow 2$ ) & \pm 0 & - & \\
\hline 25 & 400 & p.o. & 10.38 & $-1 \quad($ grade $0 \rightarrow 1)$ & \pm 0 & - & \pm 0 & - & $\gamma \mathrm{GTP}^{* * *} \uparrow$ \\
\hline 27 & 400 & p.o. & 8.23 & $-2 \quad($ grade $0 \rightarrow 2)$ & -1 & (grade $0 \rightarrow 1$ ) & \pm 0 & - & \\
\hline 28 & 400 & d.i.v. & 6.16 & \pm 0 & \pm 0 & - & -1 & $($ grade $0 \rightarrow 1)$ & \\
\hline
\end{tabular}

${ }^{*} \mathrm{LDH}$, Lactate dehydrogenase; ${ }^{* *} \mathrm{CPK}$, Creatine phosphokinase; *** $\gamma \mathrm{GTP}, \gamma$-glutamyl transpeptidase.

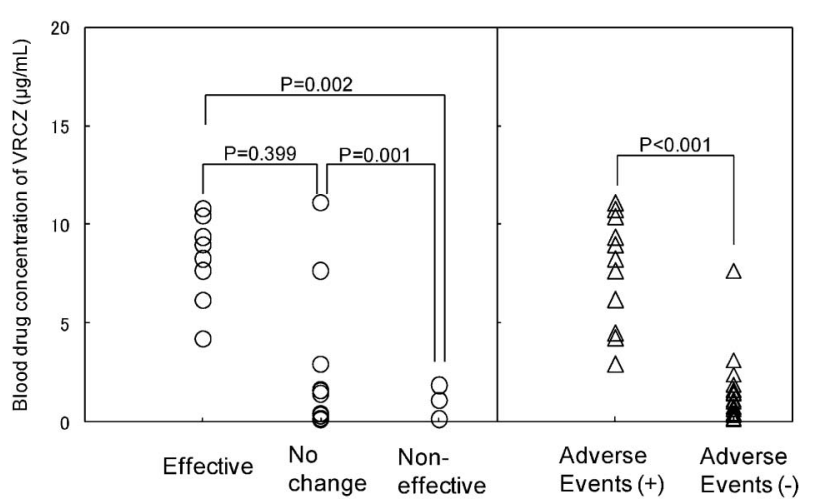

Fig. 1. Blood Drug Concentration of VRCZ and Significant Difference for Each Evaluation Significience was set at $<5 \%(p<0.05)$.

in whom VRCZ was effective than in those showing no change and in those in whom VRCZ was ineffective. The average trough blood $\mathrm{C}$ in patients in whom adverse events occurred was significantly higher (7.64 $\pm 2.84 \mu \mathrm{g} / \mathrm{ml}$ ) than that in patients in whom adverse events did not occur $(1.49 \pm 1.79 \mu \mathrm{g} / \mathrm{ml})$.

On the other hand, hepatic dysfunction was found at lower VRCZ concentrations (patients 11, 15, and 24) even though the frequency was low. In patient 11, nausea and elevated AST level were observed at a low trough blood C of $2.88 \mu \mathrm{g} / \mathrm{ml}$, and VRCZ administration was suspended (on day 7 after commencing VRCZ administration).

Although a positive correlation was seen in the relationship between trough blood $\mathrm{C}$ and dosage, a significant relationship was not observed (C: D, $y=$ $0.018-2.186, r^{2}=0.349 ; \mathrm{C}: \mathrm{d}, y=0.636-0.443, r^{2}=$
0.273) (Fig. 2). In the same manner, we also investigated the relationship excluding elderly patients 65 years of age and older and with a low VRCZ clearance; however, no significant relationship was observed $\left(\mathrm{C}: \mathrm{D}, y=0.016-2.215, r^{2}=0.331 ; \mathrm{C}: \mathrm{d}, y=\right.$ $\left.0.514+0.033, r^{2}=0.233\right)$. The blood $\mathrm{C}$ of patients receiving a normal adult dosage $(400 \mathrm{mg} /$ day $)$ ranged from $0.13 \mu \mathrm{g} / \mathrm{ml}$ to $10.75 \mu \mathrm{g} / \mathrm{ml}$. When we analyzed the relationship between the dosage and blood $\mathrm{C}$ for each patient, the trough blood $\mathrm{C}$ when the dosage was decreased to $200 \mathrm{mg} /$ day was $1.84 \mu \mathrm{g}$ / $\mathrm{ml}$ compared with $7.63 \mu \mathrm{g} / \mathrm{ml}$ in patient $\mathrm{G}$ when the same dosage was administered orally. The trough blood $\mathrm{C}$ of patient $\mathrm{P}$ at an dosage of $800 \mathrm{mg} /$ day i.v. was $11.08 \mu \mathrm{g} / \mathrm{ml}$ compared with $0.30 \mu \mathrm{g} / \mathrm{ml}$ in the same patient receiving $200 \mathrm{mg} /$ day i.v. The trough blood $\mathrm{C}$ of patient $\mathrm{U}$ at $400 \mathrm{mg}$ was $10.38 \mu \mathrm{g} / \mathrm{ml}$ but dropped to $1.07 \mu \mathrm{g} / \mathrm{ml}$ when the dosage was reduced to $200 \mathrm{mg} / \mathrm{day}$, and the levels of $\beta$-D-glucan were again observed to increase due to the calming effect after the dosage reduction.

\section{DISCUSSION}

In the present study, we evaluated the results of serologic tests to determine the relationship between trough blood $\mathrm{C}$ and both the therapeutic effect and adverse events of VRCZ. Therapeutic efficacy was observed at higher trough blood $\mathrm{C}$, and fewer adverse events were seen at lower concentrations. This indicates that the therapeutic efficacy of VRCZ depends to a large extent on its trough blood C. As with other antifungal medications, sufficient efficacy cannot be 


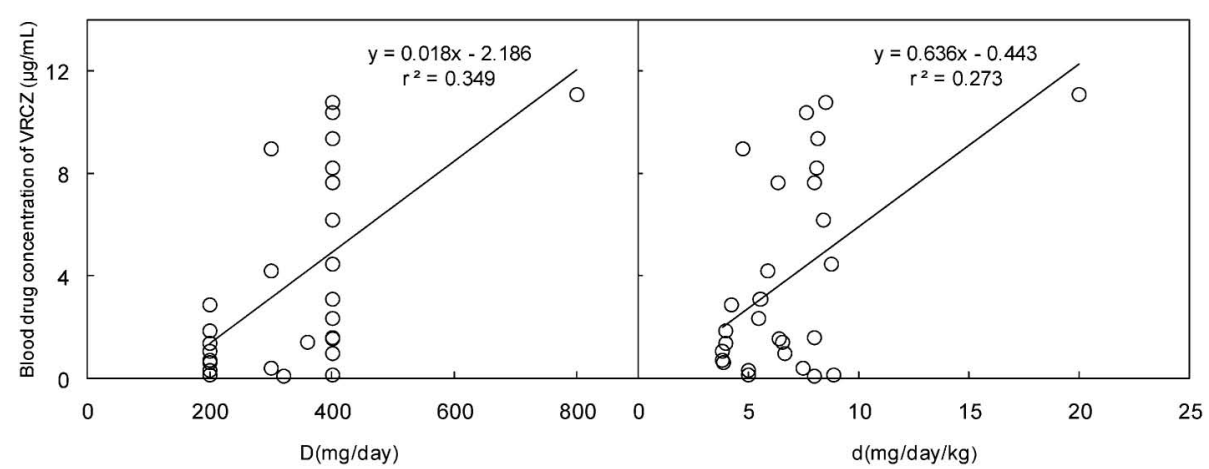

Fig. 2. Relationship between Blood Drug Concentration and Dosage of VRCZ " $\mathrm{D}$ "' as the daily dosage and " $d$ " as the daily dosage divided by the patient's weight.

obtained with low blood C of VRCZ; however, at higher levels, adverse events are more prone to occur. Based on our results, we believe that the trough blood C of VRCZ should be maintained at about $2 \mu \mathrm{g} / \mathrm{ml}$ at the least on order to achieve reliable therapeutic efficacy. Until now, limited data have been available on the use of TDM with VRCZ, but in all studies improved efficacy occurred with higher VRCZ drug concentrations. Trifilio et al. reported that all breakthrough candidiasis cases after allogeneic hematopoietic stem cell transplantation were seen among patients with VRCZ concentrations of less than $2 \mu \mathrm{g} /$ ml. ${ }^{27)}$ In addition, they suggested that VRCZ C should be maintained $>1 \mu \mathrm{g} / \mathrm{ml}$ over the entire dosing interval (trough level).16) Smith et al. found that favorable responses to VRCZ were observed in all patients with VRCZ C greater than $2.05 \mu \mathrm{g} / \mathrm{ml}^{28)}$ Those reports correspond with our results.

In addition, as previously stated, all reported cases of hepatic dysfunction in national clinical trials had trough blood $\mathrm{C}$ exceeding $4.5 \mu \mathrm{g} / \mathrm{ml}$. The present study nevertheless reflected the results obtained in these national clinical trials where adverse events were not prone to occur at high trough blood $\mathrm{C}$ exceeding $4.5 \mu \mathrm{g} / \mathrm{ml}$. However, several adverse events occurred at concentrations lower than $4.5 \mu \mathrm{g} / \mathrm{ml}$ in this study. Because the judgment standard in this study was more severe than that used in national clinical trials, more adverse events were detected in this study than in the clinical trials. It is necessary to note the slight adverse events at $\mathrm{C}$ lower than $4.5 \mu \mathrm{g} / \mathrm{ml}$ because overlooking them affects the lives of patients with fungal infections.

We found no significant relationship between dosage and trough blood C. Moreover, in each case when the dosage was changed (reduced), no significant relationship between blood $\mathrm{C}$ and dosage was seen. These findings indicate that there is no significant relationship between $\mathrm{VRCZ}$ trough blood $\mathrm{C}$ and dosage. VRCZ exhibits nonlinear pharmacokinetics, with maximum blood $\mathrm{C}$ and area under the curve increasing disproportionally with increasing dosage. ${ }^{12,14)}$ Additionally, allelic polymorphisms in CYP2C19 may result phenotypically in rapid or slow metabolism of VRCZ, possibly resulting in significant variation in the blood C. Single-nucleotide polymorphisms contributing to slow metabolism are present in higher frequencies among the Japanese than among other populations. ${ }^{10,12)}$ In other words, to obtain the optimal C of VRCZ, the dosage range must be relatively narrow, and if the suggested dosage is administered uniformly among patients, a large variation in blood $\mathrm{C}$ is likely to occur. Accordingly, when administering VRCZ, it is necessary to regulate the dosage meticulously. In this regard, the implementation of TDM for each patient to establish the optimal dosage is thought to be effective.

Based on these findings, we recommend increasing the dosage of VRCZ for patients at our facility who are receiving $<2 \mu \mathrm{g} / \mathrm{ml}$. We also suggest that our attending physicians be cautiously monitor adverse events when the concentration exceeds $4.5 \mu \mathrm{g} / \mathrm{ml}$. In these situations, although there is a nonlinear relationship between dosage and blood $\mathrm{C}$, careful regulation of the dosage must be performed while measuring blood $\mathrm{C}$ and observing for adverse events.

We plan to conduct further investigations to accumulate more detailed treatment results, establish the optimal concentration and administration method appropriate for each clinical condition, and imple- 
ment TDM with high predictive accuracy. The optimal blood C ranges of VRCZ have yet to be determined. Some reasons for the failure to establish this range are, as in the present study, the overlapping of the effective blood $\mathrm{C}$ range with the range at which adverse events occur and the extreme difficulty of establishing a concentration range at which all adverse events cease to occur. In the present study, in the optimal C range, we encountered patients in whom sufficient therapeutic efficacy was lacking, as well as patients developing hepatic damage irrespective of the low blood $\mathrm{C}$ of the drug, when administration was terminated. Thus, even if the $\mathrm{C}$ level is lower than the optimal range, it is still necessary to exercise caution with regard to the occurrence of adverse events. Furthermore, it is also necessary to observe caution regarding the recurrence of fungal infection when the $\mathrm{C}$ is reduced after determining that it is high. Thus it is recommended to start treatment for each patient only after determining the dosage at which adverse events do not occur (maximum tolerated dose). Also, it is crucial not only to monitor the blood $\mathrm{C}$ but also to regulate drug dosage while evaluating the disease from various perspectives, considering the general condition, lesion imaging findings, and underlying medical condition. Based on existing reports, we additionally investigated the relationship between trough $\mathrm{C}$ and both adverse events and therapeutic efficacy. However, investigation of their relationship to the area under the blood C-time curve and the peak value has yet to be conducted. It is therefore necessary to determine the relationship between all of these blood kinetics and therapeutic efficacy, investigating the most effective method for regulating dosage at which a therapeutic effect is achieved and at which adverse events are improbable. Currently, there is no other method than carefully regulating drug dosage by regularly measuring blood $\mathrm{C}$ and monitoring therapeutic efficacy and the occurrence of side effects. On the other hand, it may be effective to conduct a population analysis for the expression of CYP2C19 on each genotype. Based on such analysis, we believe that fungal infection can be effectively treated with the appropriate amount of VRCZ for each patient. We are presently following more cases to investigate the merits of population analysis of VRCZ.

There are many other possibilities that should be further investigated to implement TDM for VRCZ. However, we believe that the treatment of fungal in- fection is more effective when the dosage and therapeutic efficacy of VRCZ are objectively assessed through the measurement of blood $\mathrm{C}$ rather than when VRCZ is administered randomly. There have been no detailed reports investigating the optimal concentration of $\mathrm{VRCZ}$ and the regulation of its dosage. Thus the present study serves as an important foundation for implementing TDM for VRCZ. The accumulation of the present data is the first step in determining the appropriate method for TDM implementation.

\section{CONCLUSION}

Although patients with deep mycosis have a potentially, serious infectious disease, the application of the pharmacokinetics-pharmacodynamics theory has been insufficient to achieve therapeutic efficacy and there are relatively few options for drug therapy compared with the use of drugs for infectious diseases such as those caused by common bacteria. Starting with VRCZ, appropriate TDM implementation for fungal infection drug therapy is essential and should be proactively investigated. VRCZ has become an object medicine, for which a specific medicine treatment management charge can be calculated, since 2008 in Japan. The implementation of TDM for VRCZ is a valuable tool for achieving effective fungal infection therapy and should be aggressively investigated in future studies.

\section{REFERENCES}

1) Maesaki S., Iwakawa J., Higashiyama Y., Miyazaki Y., Yanagihara K., Tomono K., Tashiro T., Kohno S., J. Infect. Chemother., 6, 101-103 (2000).

2) Pfaller M. A., Messer S. A., Boyken L., Rice C., Tendolkal S., Hollis R. J., Doern G. V., Diekema D. J., J. Clin. Microbiol., 43, 21632167 (2005).

3) Pfaller M. A., Messer S. A., Boyken L., Hollis R. J., Rice C., Tendolkal S., Diekema D. J., Diagn. Microbiol. Infect. Dis., 48, 201-205 (2004)

4) Kohno S., Ogawa K., Kurashima A., Niki Y., Maesaki S., Jpn. J. Antibiot., 60, 321-334 (2007)

5) Dinning D. W., Rivaud P., Milpied N., Caillot D., Herbrecht R., Thiel E., Haas A., Ruhnke M., Lode H., Clin. Infect. Dis., 34, 563-571 
(2002).

6) Herbrecht R., Denning D. W., Patterson T. F., Bennett J. E., Greene R. E., Oestmann J. W., Kern W. V., Marr K. A., Ribaud P., Lortholary O., Sylvester R., Rubin R. H., Wingard J. R., Stark P., Durand C., Caillot D., Thiel E., Chandrasekar P. H., Hodges M. R., Schlamm H. T., Troke P. F., Pauw B. D., N. Engl. J. Med., 347, 408-415 (2002).

7) Sabbatani S., Manfredi R., Pavoni M., Consales A., Chiodo F., Mycopathologia, 158, 165-171 (2004).

8) Guideline Compilation Commission for Fungal Disease, "Guideline for Diagnosing and Remedy of Fungal Disease,' Ishiyaku Publishers, Inc., Tokyo, 2007.

9) Hyland R., Jones B. C., Smith D. A., Drug Metab. Dispos., 31, 540-547 (2003).

10) Shimizu T., Ochiai H., Asell F., Yokono Y., Kikuchi Y., Nitta M., Hama Y., Yamaguchi S., Hashimoto M., Taki K., Nakata K., Aida Y., Ohashi A., Ozawa N., Drug Metab. Pharmacokin., 18, 71-78 (2003).

11) Trifilio S., Oritiz R., Pennick G., Verma A., Pi J., Stosor V., Zembower T., Mehta J., Bone Marrow Transplant., 35, 509-513 (2005).

12) Walsh T. J., Anaissie E. J., Denning D. W., Herbrecht R., Kontoyiannis D. P., Marr K. A., Morrison V. A., Segal B. H., Steinbach W. J., Stevens D. A., van Burik J. A., Wingard J. R., Patterson T. F., Clin. Infect. Dis., 46, 327-360 (2008).

13) Andes D., Marchillo K., Stamstad T., Conklin R., Antimicrob. Agents Chemother., 47, 3165-3169 (2003).

14) Andes D., Lepak A., Nett J., Lincoln L., Marchillo K., Antimicrob. Agents Chemother., 50, 2384-2394 (2006).

15) Purkins L., Wood N., Ghahramani P., Greenhalgh K., Allen M. J., Kleinermans D., Antimicrob. Agents Chemother., 46, 2546-2553 (2002).

16) Tifilio S., Pennick G., Pi J., Zook J., Zook J., Golf M., Kaniecki K., Singhal S., Williams S.,
Winter J., Tallman M., Gordon L., Frankfurt O., Evens A., Mehta J., Cancer, 109, 15321535 (2007).

17) Marr K. A., Balajee S. A., McLaughlin L., Tabouret M., Bentsen C., Walsh T. J., J. Infect. Dis., 190, 641-649 (2004).

18) Maertens J. A., Klont R., Masson C., Theunissen K., Meersseman W., Lagrou K., Heinen C., Crepin B., Van Eldere J., Tabouret M., Donnelly J. P., Verweij P. E., Clin. Infect. Dis., 44, 1329-1336 (2007) .

19) Boutboul F., Alberti C., Leblanc T., Sulahian A., Gluckman E., Derouin F., Ribaud P., Clin. Infect. Dis., 34, 939-943 (2002).

20) Anaissie E. J., Clin. Infect. Dis., 44, 12981306 (2007).

21) Ostrosky-Zeichner L., Alexander B. D., Kett D. H., Vazquez J., Pappas P. G., Saeki F., Ketchum P. A., Wingard J., Schiff R., Tamura H., Finkelman M. A., Rex J. H., Clin. Infect. Dis., 41, 654-659 (2005).

22) Pickering J. W., Sant H. W., Bowles C. A., Roberts W. L., Woods G. L., J. Clin. Microbiol., 43, 5957-5962 (2005).

23) Odabasi Z., Mattiuzzi G., Estey E., Kantarjian H., Saeki F., Ridge R. J., Ketchum P. A, Finkelman M. A., Rex J. H., OstroskyZeichner L., Clin. Infect. Dis., 39, 199-205 (2005).

24) Horiguchi Y., Kansenshogaku Zasshi, 78, 566-573 (2004).

25) Common Terminology Criteria for Adverse Events v 3.0, Int. J. Clin. Oncol., 9, 1-82 (2004).

26) Usuki H., Inoue T., Ishida T., Miyazaki N., Med. Pharmacol., 53, 817-821 (2005).

27) Trifilio S., Singhal S., Williams S., Frankfurt O., Gordon L., Evens A., Winter J., Tallman M., Pi J., Mehta J., Bone Marrow Transplant., 40, 451-456 (2007).

28) Smith J., Safdar N., Knasinski V., Simmons W., Bhavnani S. M., Ambrose P. G., Andes D., Aintmicrob. Agents Chemother., 50, 1570-1572 (2006). 